\title{
The Analysis of Blended Learning on Student Motivation and Learning Activeness
}

\author{
Achmad Subarkat ${ }^{1}$, Ana Andriani ${ }^{2}$ \\ $\left\{\underline{\text { subarkat9@gmail.com }}\right.$, $\left.\underline{\text { ana.andriani@gmail.com }}{ }^{2}\right\}$ \\ ${ }^{1,2}$ Universitas Muhammadiyah Purwokerto
}

\begin{abstract}
This research was motivated by the low motivation and activeness of learning online in elementary schools at the time of the Covid-19 pandemic. The purpose of this study was to analyze the application of the blended learning model to the motivation and learning activeness of elementary school students. Blended learning is learning that combines face-to-face learning with online learning. This type of research is a literature study. The data obtained were collected, analyzed, and concluded to get conclusions. The literature study that has been conducted shows that the application of blended learning has an impact on motivation and learning activity. This article will further discuss in more detail the application of blended learning during the Covid-19 pandemic.
\end{abstract}

Keywords: blended learning, motivation, active learning, elementary school students

\section{Introduction}

Globalization with the development of science and technology, especially the development of transportation and communication technology, has a major impact on human life. The impact of the development of science and technology is not only positive but can also have negative impacts. Globalization gives birth to advanced science and technology products that on the one hand can facilitate the work and fulfillment of human needs, but on the other hand can cause adverse effects[1].

Transportation technology with the invention of airplanes disguises distance and time. The positive impact of transportation technology is to facilitate human mobility. The ease of human mobility from one country to another also has negative impacts, one of which is the Covid-19 pandemic. The ease of human mobility made Covid-19, which started in the Chinese city of Wuhan, finally infected almost the entire world.

The Covid-19 pandemic has an impact on various areas of life including education. Faceto-face learning is prohibited to minimize the development of positive cases of Covid-19. Learning at the beginning of the pandemic is carried out online. The development of communication technology with the discovery of cellular telephones and internet networks made it easier to implement online learning. The development of communication technology is one of the positive impacts felt by humans, especially during a pandemic. A negative impact occurs when the supervision of the use of communication technology by students is low. The ease of accessing negative things from the internet will have a negative impact on the mental and psychological development of students.

Online learning is considered less effective because there are obstacles in its implementation. Constraints faced such as non-existent network, running out of internet 
packages, homework that must be done as well, and piling up tasks[2]. Constraints in online learning result in academic stress. Academic stress is pressure due to subjective perceptions of an academic condition[3]. The pressure that appears as a form of academic stress causes various reactions from students. Reactions to academic stress can include thoughts, behavior, body reactions, and feelings. Academic stress reactions in the form of thoughts, behavior, and body reactions are closely related to student motivation and learning activity. Statements from some of these sources indicate that online learning causes academic stress to students, thereby reducing motivation and learning activeness.

Online learning that is considered less effective as well as starting the decline in the Covid19 pandemic has encouraged teachers to carry out blended learning. Blended Learning is a mixed learning model that combines face-to-face learning with online learning. The application of face-to-face learning was initially carried out by the teacher by visiting small groups at students' homes. Next, the teacher started inviting the small groups to school. Online learning takes advantage of various digital platforms such as google classroom, zoom, google meet, youtube, and WhatsApp. The choice of platform is adjusted to the ability of students and parents to use it. Based on this description, the purpose of this study is to analyze the application of the blended learning model to the motivation and learning activeness of elementary school students during the Covid-19 pandemic.

\section{Research Method}

The method used in this research is a literature study. Literature study research is a research activity carried out by collecting information and data with the help of various materials in the library such as reference books, similar results of previous research, articles, notes, and various journals related to the problem to be solved[4]. The data used in this research is secondary data with data collection techniques in the form of documentation. Documentation technique is a way of collecting data, through written legacy, such as archives and books on opinions, theories, propositions, or laws, and related to research problems[5]. The data analysis technique used is content analysis. The steps of content analysis according to Fraenkel and Wallen are: The researcher decides the specific goals to be achieved, defines important terms that must be explained in detail, specifies the unit to be analyzed, looks for relevant data, builds rational or conceptual relationships to explain how a data relating to objectives, planning sampling, and formulating category coding[6].

\section{Results and Discussion}

Blended learning is one of the innovations to be able to increase student interest in learning. Blended learning allows learning to be carried out more varied. Variations in the learning process can increase students' enthusiasm for learning[7]. Henzi and Procter in Abdullah further describes the concept of blended learning as follows on Figure 1 [8].

Blended Learning is a learning model that mixes face-to-face learning with online learning. Online learning is complemented by the development of video conferencing and webchat between students and students, but students and teachers still need direct interaction with each other[9]. The teacher acts as a teacher and educator. As educators who teach valuesor character, teachers need to interact directly with students in the learning process. 


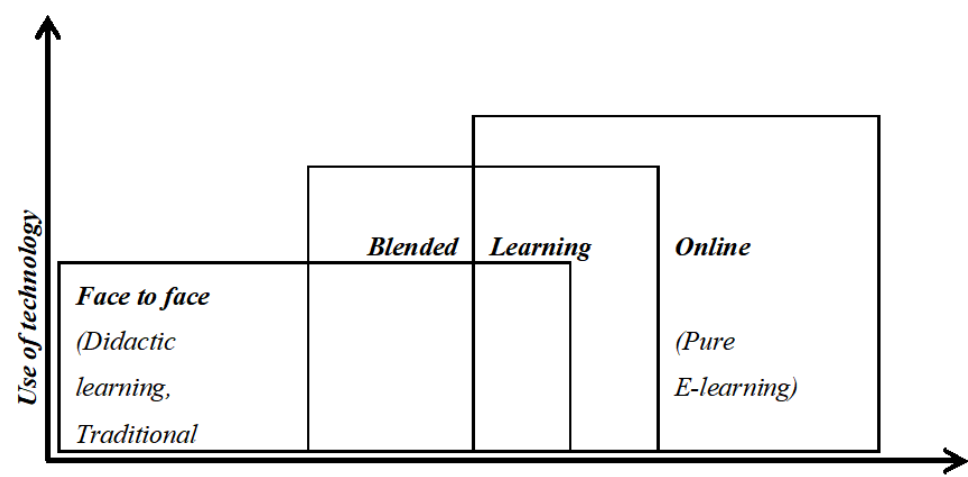

Time spent on "online learning"

Figure 1. Henzi and Procter's Blended Learning Concept

The essence of blended learning is a combination of face-to-face learning and online learning. The distribution of composition between face-to-face and online is based on the various needs in learning and the situation and conditions that are being faced. These situations and conditions include student abilities and characteristics, subjects, delivery strategies, resources, and student locations. The location of students will be an important consideration in the implementation of blended learning. This location is related to access, both internet access and geographic access, especially in rural areas.

Motivation is the driving force for someone to carry out activities that have a purpose and as a determinant of individual behavior[10]. The driving factor as motivation is divided into two, namely internal and external factors. The existence of students' internal motivation has a stronger effect on the effort or action taken than external motivation. Internal motivation raises a desire or self-awareness so that a person will move without the need for external stimulation. Internal factors relate to the desire and desire to succeed and encourage learning needs, expectations of ideals, while external factors can be in the form of rewards, a conducive learning environment, and interesting learning activities.

Motivation as a driving factor also means the process of giving encouragement, direction, and persistence of behavior[11]. Student learning motivation means encouragement in the form of enthusiasm, direction, and persistence of students in taking learning actions to achieve their learning goals. Without motivation, a person cannot act because in essence motivation is an impulse in a person to move.

This research is a research with a literature study method. The main data sources in this study are literature and the results of similar studies that have been conducted. The data obtained were then analyzed using content analysis techniques. Blended learning combines face-to-face and online learning to provide a dynamic learning experience. Learning experience dynamics in blended learning, especially when learning is carried out online so that learning occurs asynchronously. Asynchronous learning creates learning conditions that are constantly changing so that students do not feel bored. Dynamic elements in learning become one of the driving forces for student motivation in learning [12].

Learning activeness includes the active thinking and actions of students in the learning process. Activeness is divided into two, namely physical and spiritual activity. Physical activity is the activity that can be observed by others. Physical activity is done by seeing, reading, listening, listening, speaking, writing, and demonstrating. Unlike physical activity, spiritual or 
mental activity cannot be observed by others. Spiritual activity is related to the mental and emotional of students.

Learning activeness includes three learning processes, namely: the preparation process, the learning process, and the assessment process[13]. One of the activeness of students in the learning process is direct learning involvement. Direct learning involvement in blended learning occurs during face-to-face learning. Physical activeness includes visual activeness, verbal, listening, movement, and writing[14]. The blended learning process allows learning to be carried out more varied, especially in visual, verbal, and listening activeness. Variable learning can increase student activity in learning [15].

The effect of blended learning on motivation and learning activeness is evidenced by several studies that have been conducted. Blended learning research on motivation results in an increase in learning motivation in classes using blended learning[16]. Blended learning research on learning activeness with results the percentage of students' learning activeness scores have increased in each research cycle[17-18].

\section{Conclusion}

There are deficiencies in face-to-face learning and online learning. Synchronous face-toface learning is less dynamic so students will quickly feel bored. Online learning also has drawbacks because direct interaction between teachers and students is still needed, especially in the process of forming student character. Blended learning combines best practices between face-to-face and online learning. The implementation of blended learning can be done with various compositions between face-to-face and online learning. The composition is adapted to various needs such as content, existing facilities, and geographic conditions that affect the internet network at the time of online learning.

Data analysis was carried out using content analysis techniques from the literature and research that had been done, it can be concluded that the application of blended learning affects student motivation and learning activeness. The effect obtained is that blended learning can increase motivation and learning activeness. Blended learning creates dynamic and varied learning. Dynamic learning can encourage learning motivation, while varied learning affects students' learning activeness.

\section{References}

[1] Maolia N, Bramasta D, Andriani A. SIKAP TOLERANSI DAN TANGGUNG JAWAB SISWA KELAS V SD NEGERI 1 PATIKRAJA. Malih Peddas (Majalah Ilmiah Pendidikan Dasar). 2019;9(1):22-9.

[2] Harahap AC, Harahap DP, Harahap SR. Analisis Tingkat Stres Akademik Pada Mahasiswa Selama Pembelajaran Jarak Jauh Dimasa Covid-19. Biblio Couns: Jurnal Kajian Konseling dan Pendidikan. 2020 Mar 30;3(1):10-4.

[3] Barseli M, Ifdil I, Nikmarijal N. Konsep stres akademik siswa. Jurnal konseling dan pendidikan. 2017 Dec 28;5(3):143-8.

[4] Sari M, Asmendri A. Penelitian Kepustakaan (Library Research) dalam Penelitian Pendidikan IPA. Natural Science: Jurnal Penelitian Bidang IPA Dan Pendidikan IPA. 2020 Jun 10;6(1):41-53., (4153), ISSN: 2715-470X(Online), 2477 - 6181

[5] Moleong LJ. Metodologi penelitian kualitatif. PT Remaja Rosdakarya; 2021 Jun 25.

[6] Mirzaqon. T, A dan Purwoko, B. Studi Kepustakaan Mengenai Landasan Teori dan Praktik Konseling Expressive Writing. Jurnal BK Unesa, 2017:8(1).

[7] Sagala, S. Konsep dan Makna Pembelajaran. Bandung: Alfabeta. 2006.

[8] Abdullah W. Model blended learning dalam meningkatkan efektifitas pembelajaran. Fikrotuna. 2018 Jul 29;7(1):855-66

[9] Husamah. Pembelajaran Bauran (Blended Learning). Jakarta: Prestasi Pustakarya. 2014. 
[10] Firdaus S, Isnaeni W, Ellianawati E. Motivation and learning achievement of primary students in theme-based learning using blended learning model. Journal of Primary Education. $2018 \mathrm{Jul}$ 27;7(3):324-31.

[11] Suprijono A. Cooperative Learning: Teori\&Aplikasi PAIKEM. Yogyakarta: Pustaka Pelajar. 2013.

[12] Siregar E. Teori Belajar dan Pembelajaran. Bogor: Ghalia Indonesia. 2014.

[13] Sanjaya W. Strategi Pembelajaran Berorientasi Standar . Jakarta: Prenada Media Group. (2010).

[14] Daryanto KS. Pembelajaran Abad 21. Yogyakarta: Gava Media. 2007.

[15] Amalia RR, Anggoro S, Eka KI. Identification of Teachers and Students' Readiness to E-Learning Implementation. JOURNAL OF TEACHING AND LEARNING IN ELEMENTARY EDUCATION (JTLEE).;4(2):170-9.

[16] Islam S, Baharun H, Muali C, Ghufron MI, el Iq Bali M, Wijaya M, Marzuki I. To boost students' motivation and achievement through blended learning. InJournal of Physics: Conference Series 2018 Nov 1 (Vol. 1114, No. 1, p. 012046). IOP Publishing.

[17] Purwitasari DI, Astawa IW, Sudiarta IG. Penerapan blended learning berbantuan schoology untuk meningkatkan keaktifan dan prestasi belajar matematika siswa kelas VIII A1 SMP Negeri 6 Singaraja. Jurnal Pendidikan dan Pembelajaran Matematika Indonesia. 2019;8(2):143-52.

[18] Aida TN, Anggoro S, Andriani A. Analisis Berpikir Kritis Siswa Melalui Model POE (PredictObserve-Explain) di Sekolah Dasar. Jurnal Elementaria Edukasia. 2019;2(2):164-72. 